\title{
Widespread Existence of Quorum Sensing Inhibitors in Marine Bacteria: Potential Drugs to Combat Pathogens with Novel Strategies
}

\author{
Jing Zhao ${ }^{1,2}$, Xinyun $\mathrm{Li}^{1,2}$, Xiyan Hou ${ }^{1,2}$, Chunshan Quan ${ }^{1,2, *}$ and Ming Chen ${ }^{3, *}$ \\ 1 Key Laboratory of Biotechnology and Bioresources Utilization (Dalian Minzu University), Ministry of \\ Education, Dalian 116600, China; zhaojing@dlnu.edu.cn (J.Z.); lixinyun9118@163.com (X.L.); \\ xyhous@dlnu.edu.cn (X.H.) \\ 2 College of Life Science, Dalian Minzu University, Dalian 116600, China \\ 3 School of Biological Engineering, Dalian Polytechnic University, Dalian 116600, China \\ * Correspondence: mikyeken@dlnu.edu.cn (C.Q.); chenming@dlpu.edu.cn (M.C.); \\ Tel.: +86-411-8765-6219 (C.Q.); +86-411-8631-8769 (M.C.)
}

Received: 4 April 2019; Accepted: 29 April 2019; Published: 8 May 2019

\begin{abstract}
Quorum sensing (QS) is a phenomenon of intercellular communication discovered mainly in bacteria. A QS system consisting of QS signal molecules and regulatory protein components could control physiological behaviors and virulence gene expression of bacterial pathogens. Therefore, QS inhibition could be a novel strategy to combat pathogens and related diseases. QS inhibitors (QSIs), mainly categorized into small chemical molecules and quorum quenching enzymes, could be extracted from diverse sources in marine environment and terrestrial environment. With the focus on the exploitation of marine resources in recent years, more and more QSIs from the marine environment have been investigated. In this article, we present a comprehensive review of QSIs from marine bacteria. Firstly, screening work of marine bacteria with potential QSIs was concluded and these marine bacteria were classified. Afterwards, two categories of marine bacteria-derived QSIs were summarized from the aspects of sources, structures, QS inhibition mechanisms, environmental tolerance, effects/applications, etc. Next, structural modification of natural small molecule QSIs for future drug development was discussed. Finally, potential applications of QSIs from marine bacteria in human healthcare, aquaculture, crop cultivation, etc. were elucidated, indicating promising and extensive application perspectives of QS disruption as a novel antimicrobial strategy.
\end{abstract}

Keywords: marine bacteria; QS inhibitors; small molecule QS inhibitors; quorum quenching enzymes; QS inhibition mechanisms; structural modification; application

\section{Introduction}

Quorum sensing (QS) has been recognized as a widespread phenomenon in bacteria. To date, QS systems have been elucidated in detail in many different bacterial species, especially in Vibrio. In QS systems, signal molecules are secreted by bacteria in a cell density-dependent manner and induce signal transduction through cascaded QS regulatory proteins [1,2]. Signal molecule-mediated QS would participate in regulation of multiple phenotypes and important physiological functions, including cell metabolism, release of virulence factors, stress response, etc., in bacteria [3,4].

Recently, QS-mediated virulence expression, biofilm formation, and colonization of pathogenic bacteria have aroused great concern [5-7]. Due to the multidrug resistance of certain pathogens, QS interruption or inhibition seemed to be a promising strategy to combat pathogen infection $[8,9]$. QS interruption can be performed through mainly three mechanisms: blocking the synthesis of signaling molecules, degradation of signaling molecules, and impeding the binding of signaling 
molecules to receptor proteins in QS pathways $[10,11]$. Theoretically, QS interruption can be realized through different methods based on above mechanisms. However, certain methods are not feasible, e.g., reconstruction of bacterial metabolic pathways to inhibit the synthesis of signal molecules or changing environmental conditions ( $\mathrm{pH}$ and temperature) for chemical degradation of signal molecules. QS inhibitors (QSIs), due to their feasibility and applicability in combating pathogens, are widely studied in recent years.

QSIs mainly include two types: one type is small molecule QSIs either extracted from natural resources or obtained by chemical synthesis [12,13], and the other type is quorum quenching enzymes, mainly including acylases, lactonases targeting acyl-homoserine lactones (AHLs) as signaling molecules, AI-2 kinases targeting furanosyl borate ester (autoinducer 2, AI-2) as signaling molecules, etc. [14-16]. Natural QSIs have attracted great attention due to three reasons: firstly, natural resources have enormous potential to be tapped; secondly, structural modification based on natural QSIs would likely to provide novel QSIs with higher efficiency; and thirdly, natural QSIs are expected to be environmentally compatible and safe, which is beneficial for novel drug development and environment governance. Natural QSIs have been identified in both prokaryotic and eukaryotic origin, which include both terrestrial animals, plants, microorganisms and marine organisms [12,17-20]. To date, QSIs or organisms with QS inhibition capability have been found in vast marine resources. Unlike quorum quenching enzymes which were discovered mainly from marine bacteria extracts, small molecule QSIs originated from more diversified sources, including marine animals, algae, sponge, coral, fungi, and bacteria in the broad sense [21-26]. Also, certain marine-derived microorganisms were discovered with QS inhibition activity without identification of QS inhibitory substances [27].

To date, many small molecule QSIs from marine microorganisms have been mentioned and researched [28]. In this article, we made a systematical elaboration of marine bacteria with QS inhibition capabilities and their production of QSIs. We first summarized the screening of marine bacteria with QS inhibition capabilities. Afterwards, two types of marine bacteria-derived QSIs-small molecule QSIs and quorum quenching enzymes-were elucidated respectively from the aspects of sources, structures, QS inhibition mechanisms, environmental tolerance, effects/applications, etc. Structural modification of small molecule QSIs for higher efficiency was further focused for future drug development. Finally, QS inhibition mechanisms and potential applications of the marine bacteria-derived inhibitors were elucidated.

\section{Screening and Classification of Marine Bacteria with QS Inhibition Capabilities}

To discover QSIs in the vast marine bacteria sources, many researchers have used different screening methods or systems for prescreening or large-scale screening of marine bacteria with potential QS inhibition capabilities. The commonly used screening systems are based on phenotype changes of biosensor reporter strains, including bioluminescence of Vibrio harveyi BB120, Escherichia coli pSB1075, Pseudomonas aeruginosa PAO-JP2, pigment production of Serratia marcescens SP15, Serratia rubidaea JCM 14263, Chromobacterium violaceum CV026 and DSM 30191, VIR07, $\beta$-galactosidase activity of Agrobacterium tumefaciens A136, KYC55, NTL4, etc. Screening based on the biosensor strains is a simple and high-throughput method for exploring marine bacteria with QS inhibition activity. Besides the biosensor strains, metagenomic sequencing was also used for rapid and large screening of QS-inhibitory bacteria in recent years, which can unveil the frequency of quorum quenching enzyme sequences in marine bacteria [29]. This technique avoids the defects of biosensor reporter strains, which could only detect the QS inhibition activity of cultivable bacteria. Also, marine metagenomic sequencing provides a comprehensive search for putative quorum quenching enzymes, thus providing a vast reservoir of marine-derived quorum quenching enzymes for research and utilization.

Screening from various marine environments using either biosensor strains or metagenomic sequencing showed abundance of QS-inhibitory marine bacteria (Figure 1) [30-49]. It could be seen that QS-inhibitory marine bacteria were mainly screened out from sea waters, marine sediments, 
as well as marine invertebrates, fish, algae, etc. These origins scattered in different regions and cities in the world.

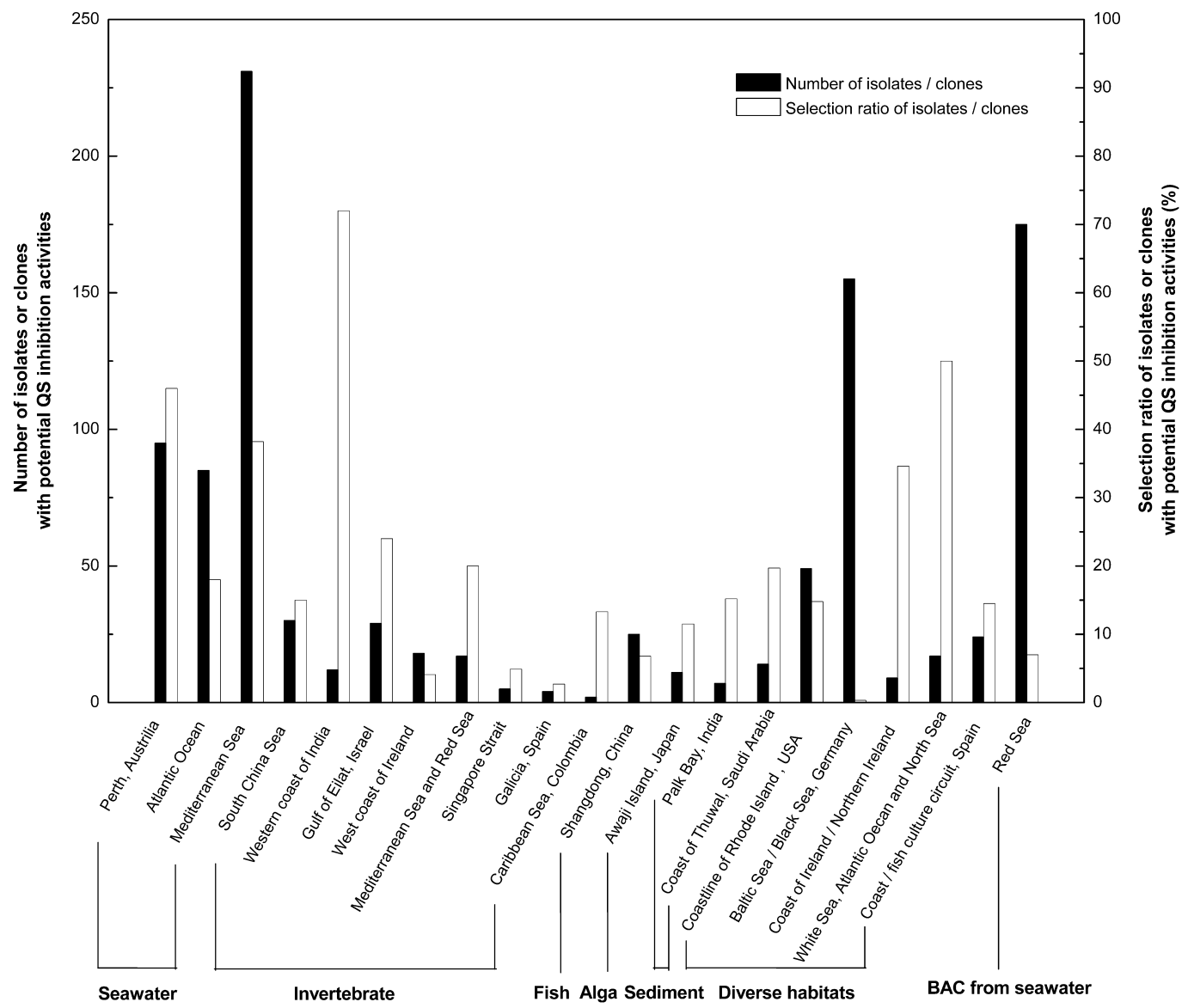

Figure 1. Large-scale prescreening showed abundance of marine bacteria with potential quorum sensing (QS) inhibition activities.

In large-scale screening of QS-inhibitory bacteria, three interesting phenomena were found. First, marine bacteria might not only have the ability to interfere with AHL-mediated QS, but also have the ability to interfering with AI-2/QS systems [39,45], indicating a wide application of QS-inhibitory marine bacteria against pathogens with both AHL and AI-2 mediated QS systems. Another notable point was that the depth of sea water might positively correlate with the quantity of QS-inhibitory marine bacteria discovered. This discovery might guide us to explore deep sea microorganisms for QS inhibitory substances. Thirdly, it is interesting to notice that pathogens associated with marine eukaryotes also have QS-inhibitory activities, which might help pathogens compete for adhesion with other bacteria that foul the surfaces of marine eukaryotes with biofilm formation $[34,45]$. The living of pathogens via QS-interfering is worth studying for future prevention of certain marine bacterial diseases. Of course, prescreening results might not be quite accurate and false positive results might always exist, since different biosensor reporter strains and different culture media for screening might vary in effectiveness for bacteria isolation $[34,35,38]$.

Based on screening, many researches have isolated one or several QS-inhibitory bacteria strains from marine origins. The identified bacteria, which have potential QS inhibition ability but have not been further explored for specific QSIs, were categorized in Figure 2 [33-35,37,38,40-44,46-55]. Statistically, QS-inhibitory bacteria could be divided into four phylums and five classes. The phylums include Proteobacteria (47.22\%), Firmicutes (37.78\%), Bacteroidetes $(8.89 \%)$, and Actinobacteria $(6.11 \%)$. The five classes include Alphaproteobacteria (20.56\%), Gammaproteobacteria (26.67\%), Actinobacteria (6.11\%), Bacilli (37.78\%), and Flavobacteria (8.89\%). 

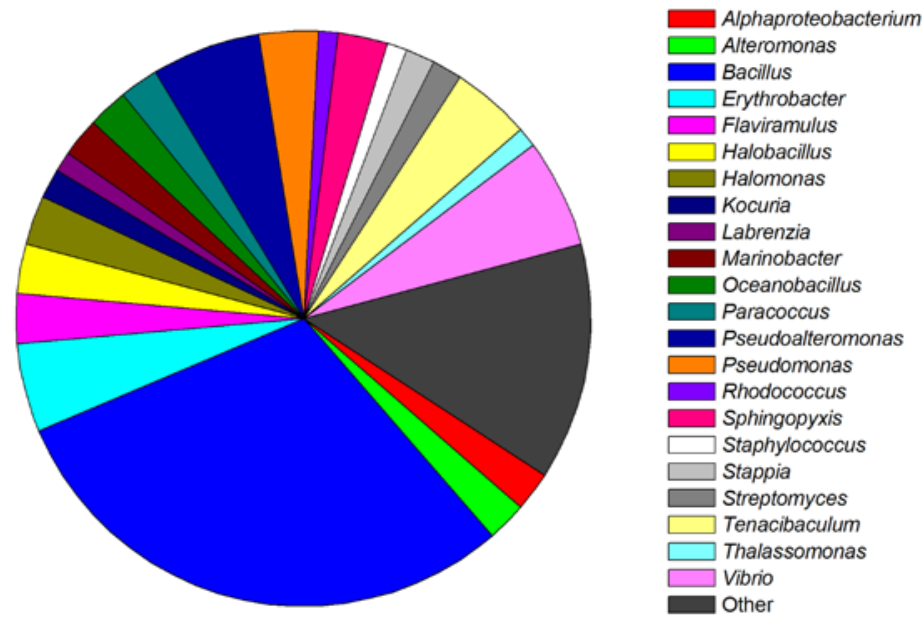

Figure 2. Classification and relative abundance of the marine bacteria isolates with potential QS inhibition activities. The genera represented by a single isolate are grouped as "other".

Besides many QS-inhibitory bacteria that have been identified, certain QS-inhibitory marine bacteria cultures remained to be disclosed. Tinh et al. isolated AHL-degrading bacterial enrichment cultures from the digestive tract of Pacific white shrimps. One of the enrichment cultures could improve turbot larvae survival, possibly through a QS-interference strategy. However, since the enrichment cultures contained a variety of bacteria, the species with actual AHL-degrading ability remained to be identified [56,57]. Cam et al. also isolated AHL-degrading bacterial enrichment cultures from the gut of European Seabass in Belgium and Asian Seabass in Vietnam, which could improve prawn larvae survival [58]. Also, the enrichment culture remained to be studied further.

The vast resource of QS-inhibitory marine bacteria needs to be further explored. To confirm the QS-inhibitory activity of bacteria, purification of the active substance, high-performance liquid chromatography-mass spectrometry (HPLC-MS) analysis and usage of other techniques should be carried out, either to identify the chemical structures of small molecule QSIs or to detect the degradation of QS signal molecules by quorum quenching enzymes. 
Table 1. Small molecule QS inhibitors. Structures, origin, working concentrations, mechanisms and effects.

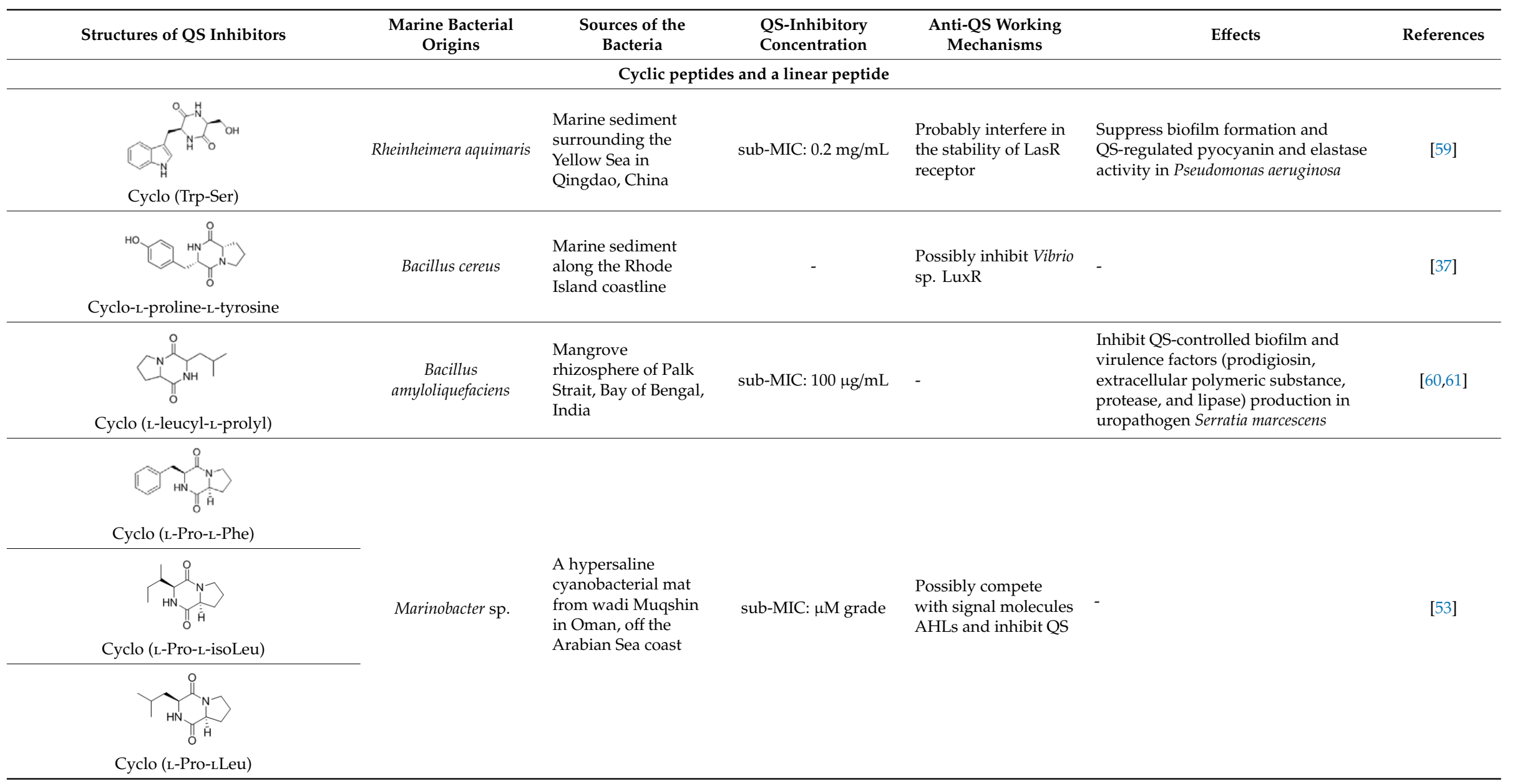


Table 1. Cont.

\begin{tabular}{|c|c|c|c|c|c|c|}
\hline Structures of QS Inhibitors & $\begin{array}{l}\text { Marine Bacterial } \\
\text { Origins }\end{array}$ & $\begin{array}{l}\text { Sources of the } \\
\text { Bacteria }\end{array}$ & $\begin{array}{l}\text { QS-Inhibitory } \\
\text { Concentration }\end{array}$ & $\begin{array}{l}\text { Anti-QS Working } \\
\text { Mechanisms }\end{array}$ & Effects & References \\
\hline $\begin{array}{l}\text { Ngercheumicin } \mathrm{F}(\mathrm{R}=\mathrm{C} 11 \mathrm{H} 21), \\
\text { Ngercheumicin } \mathrm{G}(\mathrm{R}=\mathrm{C} 11 \mathrm{H} 23), \\
\text { Ngercheumicin } \mathrm{H}(\mathrm{R}=\mathrm{C} 13 \mathrm{H} 25), \\
\text { Ngercheumicin } \mathrm{I}(\mathrm{R}=\mathrm{C} 13 \mathrm{H} 27)\end{array}$ & $\begin{array}{l}\text { Photobacterium } \\
\text { halotolerans }\end{array}$ & $\begin{array}{l}\text { Mussel surface in the } \\
\text { tropical Pacific }\end{array}$ & $20 \mu \mathrm{g} / \mathrm{mL}$ & Interfere with agr QS & $\begin{array}{l}\text { Reduce expression of virulence genes } \\
\text { of hla (hemolysin) and rnaIII (an } \\
\text { effector molecule) of agr QS in } \\
\text { Staphylococcus aureus }\end{array}$ & [62] \\
\hline $\begin{array}{c}\text { Solonamide A } \\
\text { (Fatty acid-L-Phe- } \\
\text { D-Leu-D-Ala-L-Leu) }\end{array}$ & \multirow[t]{2}{*}{$\begin{array}{l}\text { Photobacterium } \\
\text { halotolerans }\end{array}$} & \multirow[t]{2}{*}{$\begin{array}{l}\text { Mussel surface in the } \\
\text { tropical Pacific }\end{array}$} & \multirow[t]{2}{*}{$\mu \mathrm{g} / \mathrm{mL}-\mathrm{mg} / \mathrm{mL}$} & \multirow[t]{2}{*}{$\begin{array}{l}\text { Possibly interfere } \\
\text { with the agr QS } \\
\text { system by competing } \\
\text { with AIP for binding } \\
\text { to sensor histidine } \\
\text { kinase AgrC }\end{array}$} & \multirow[t]{2}{*}{$\begin{array}{l}\text { Inhibit virulence gene expression of hla } \\
\text { (hemolysin), rnaIII (an effector } \\
\text { molecule of agr) and psm } \alpha \text { (phenol } \\
\text { soluble modulins) in Staphylococcus } \\
\text { aureus, and reduce toxicity of S. aureus } \\
\text { toward human neutrophils }\end{array}$} & \multirow[t]{2}{*}[63,64]{} \\
\hline $\begin{array}{c}\text { Solonamide B } \\
\text { (Fatty acid-L-Phe- } \\
\text { D-Leu-D-Ala-L-Leu) }\end{array}$ & & & & & & \\
\hline Linear dipeptide proline-glycine & Streptomyces sp. & $\begin{array}{l}\text { Marine invertebrates } \\
\text { from the western } \\
\text { coast of India }\end{array}$ & sub-MIC: $0.1 \mathrm{mg} / \mathrm{mL}$ & - & $\begin{array}{l}\text { Inhibit QS-mediated virulence factors } \\
\text { (swarming, pyocyanin pigmentation, } \\
\text { biofilm formation, rhamnolipid } \\
\text { production, and Las A) in Pseudomonas } \\
\text { aeruginosa }\end{array}$ & [32] \\
\hline
\end{tabular}


Table 1. Cont.

\begin{tabular}{|c|c|c|c|c|c|c|}
\hline Structures of QS Inhibitors & $\begin{array}{l}\text { Marine Bacterial } \\
\text { Origins }\end{array}$ & $\begin{array}{l}\text { Sources of the } \\
\text { Bacteria }\end{array}$ & $\begin{array}{l}\text { QS-Inhibitory } \\
\text { Concentration }\end{array}$ & $\begin{array}{l}\text { Anti-QS Working } \\
\text { Mechanisms }\end{array}$ & Effects & References \\
\hline \multicolumn{7}{|c|}{ Amides } \\
\hline 2-Methyl- $N$-(2'-phenylethyl) butyramide & Oceanobacillus sp. & Marine environment & $\begin{array}{l}\text { sub-MIC: } \mu \mathrm{g} / \mathrm{mL} \\
\quad \text { grade }\end{array}$ & - & $\begin{array}{l}\text { Inhibit pyocyanin production, elastase } \\
\text { activity and biofilm formation of } \\
\text { Pseudomonas aeruginosa }\end{array}$ & [65] \\
\hline$N$-(2'-Phenylethyl)-isobutyramide & Halobacillus salinus & $\begin{array}{l}\text { Sea grass sample from } \\
\text { Point Judith Salt } \\
\text { Pond, Rhode Island }\end{array}$ & $\begin{array}{l}\text { sub-MIC: } \mu \mathrm{g} / \mathrm{mL} \\
\text { grade }\end{array}$ & $\begin{array}{l}\text { Possibly compete } \\
\text { with AHLs for } \\
\text { receptor binding }\end{array}$ & - & [66] \\
\hline $\begin{array}{l}\text { 8-epi-Malyngamide C (8R) and malyngamide } \\
C(8 S)\end{array}$ & $\begin{array}{l}\text { cyanobacterium } \\
\text { Lyngbya majuscula }\end{array}$ & Off Bush Key, Florida & $\mu \mathrm{M}$ grade & - & - & [67] \\
\hline \multicolumn{7}{|l|}{ Fatty Acids and phenol derivatives } \\
\hline cinnamic acid & Streptomyces sp. & $\begin{array}{l}\text { Marine invertebrates } \\
\text { from the western } \\
\text { coast of India }\end{array}$ & sub-MIC: $0.1 \mathrm{mg} / \mathrm{mL}$ & - & $\begin{array}{l}\text { Inhibit QS-mediated virulence factors } \\
\text { (swarming, biofilm formation, LasA, } \\
\text { pyocyanin and rhamnolipid } \\
\text { production) in Pseudomonas aeruginosa }\end{array}$ & [32] \\
\hline $\begin{array}{c}\text { OH } \mathrm{OH} \\
\text { (degradation product of } \mathrm{PHB} \text { ) }\end{array}$ & $\begin{array}{l}\text { Brevibacterium casei } \\
\text { (sources of PHB) }\end{array}$ & $\begin{array}{l}\text { Marine sponge } \\
\text { Dendrilla nigra }\end{array}$ & $50 \mu \mathrm{g} / \mathrm{mL}$ (PHB) & $\begin{array}{l}\text { Possibly by AHL } \\
\text { degradation }\end{array}$ & $\begin{array}{l}\text { Control biofilm formation, } \\
\text { colonization capacity, motility and } \\
\text { hemolysin activity of Vibrio sp. }\end{array}$ & [68] \\
\hline
\end{tabular}


Table 1. Cont.

\begin{tabular}{|c|c|c|c|c|c|c|}
\hline Structures of QS Inhibitors & $\begin{array}{l}\text { Marine Bacterial } \\
\text { Origins }\end{array}$ & $\begin{array}{l}\text { Sources of the } \\
\text { Bacteria }\end{array}$ & $\begin{array}{l}\text { QS-Inhibitory } \\
\text { Concentration }\end{array}$ & $\begin{array}{c}\text { Anti-QS Working } \\
\text { Mechanisms }\end{array}$ & Effects & References \\
\hline Lyngbyoic acid & $\begin{array}{c}\text { cyanobacterium } \\
\text { Lyngbya cf. majuscula }\end{array}$ & $\begin{array}{l}\text { Indian River Lagoon } \\
\text { near Fort Pierce, } \\
\text { Florida }\end{array}$ & $\mu \mathrm{M}-\mathrm{mM}$ grade & $\begin{array}{l}\text { Possibly inhibit lasR } \\
\text { signaling by } \\
\text { competing with AHL } \\
\text { for binding LasR }\end{array}$ & $\begin{array}{l}\text { Reduce pyocyanin and elastase (LasB) } \\
\text { in Pseudomonas aeruginosa }\end{array}$ & [69] \\
\hline Lyngbi & cyanobacterium & $\begin{array}{l}\text { Corals from the } \\
\text { Florida Keys and } \\
\text { Belize }\end{array}$ & $\mathrm{nM}-\mu \mathrm{M}$ grade & $\begin{array}{l}\text { Compete with CAI-1 } \\
\text { for binding to QS } \\
\text { signal receptor CqsS }\end{array}$ & - & [70] \\
\hline Pitinoic acid A & $\begin{array}{l}\text { cyanobacterium } \\
\text { similar to Lyngbya sp. }\end{array}$ & $\begin{array}{l}\text { A channel at the north } \\
\text { end of Piti Bay at } \\
\text { Guam }\end{array}$ & $\begin{array}{l}\text { sub-MIC: } \mu \mathrm{M}-\mathrm{mM} \\
\text { grade }\end{array}$ & - & $\begin{array}{l}\text { Inhibit expression of QS-related } \\
\text { virulence factor LasB (elastase) and the } \\
\text { pyocyanin in Pseudomonas aeruginosa }\end{array}$ & [71] \\
\hline Phenol, 2,4-bis (1,1-dimethylethyl) & Vibrio alginolyticus & $\begin{array}{l}\text { Red seaweed } \\
\text { Gracilaria gracilis from } \\
\text { the Karankadu } \\
\text { coastal region of Palk } \\
\text { Bay, India }\end{array}$ & $\begin{array}{l}\text { sub-MIC: } \mu \mathrm{g} / \mathrm{mL} \\
\text { grade }\end{array}$ & - & $\begin{array}{l}\text { Inhibit QS-mediated biofilm formation } \\
\text { and virulence factor production } \\
\text { (protease, hemolysin, lipase, } \\
\text { prodigiosin, and extracellular } \\
\text { polysaccharide) in the uropathogen } \\
\text { Serratia marcescens }\end{array}$ & [72] \\
\hline $\mathrm{OH}$ & $\begin{array}{l}\text { Oceanobacillus } \\
\text { profundus }\end{array}$ & $\begin{array}{l}\text { Caribbean soft coral } \\
\text { Antillogorgia } \\
\text { elisabethae }\end{array}$ & - & - & - & [49] \\
\hline Tyrosol/tyrosol acetate ( $\mathrm{R}=\mathrm{H}$ or $\mathrm{Ac})$ & & & & & & \\
\hline
\end{tabular}

AHL analogs

$$
\sim \mathrm{N}^{\mathrm{O}} \mathrm{Co}^{\mathrm{O}}
$$

N-(3-Hydroxydecanoyl)-L-homoserine lactone

N-(Dodecanoyl-2,5-diene)-L-homoserine

Phaeobacter inhibens Inner surface of an oyster shell
Possibly by competitive inhibition Inhibit virulence factor metalloprotease in Vbrio coralliilyticus

O-(3-Hydroxytetradecanoyl-7-ene)-L-homoserine lactone 
Table 1. Cont.

\begin{tabular}{|c|c|c|c|c|c|c|}
\hline Structures of QS Inhibitors & $\begin{array}{l}\text { Marine Bacterial } \\
\text { Origins }\end{array}$ & $\begin{array}{l}\text { Sources of the } \\
\text { Bacteria }\end{array}$ & $\begin{array}{l}\text { QS-Inhibitory } \\
\text { Concentration }\end{array}$ & $\begin{array}{l}\text { Anti-QS Working } \\
\text { Mechanisms }\end{array}$ & Effects & References \\
\hline D,L-Homocysteine thiolactone & Staphylococcus hominis & $\begin{array}{l}\text { coral species } \\
\text { (Pocillopora damicornis) } \\
\text { in Xishan Islands, } \\
\text { South China Sea }\end{array}$ & above $0.0625 \mu \mathrm{g} / \mathrm{mL}$ & $\begin{array}{l}\text { Possibly compete } \\
\text { with AHL in } \\
\text { occupying the AHL } \\
\text { receptor }\end{array}$ & $\begin{array}{l}\text { Suppress biofilm formation and } \\
\text { elastase production in Pseudomonas } \\
\text { aeruginosa }\end{array}$ & [31] \\
\hline \multicolumn{7}{|c|}{ Others } \\
\hline Honaucin A & \multirow{3}{*}{$\begin{array}{l}\text { cyanobacterium } \\
\text { Leptolyngbya } \\
\text { crossbyana }\end{array}$} & \multirow{3}{*}{$\begin{array}{l}\text { Corals on the } \\
\text { Hawaiian coast }\end{array}$} & \multirow{3}{*}{$\mu \mathrm{M}$ grade } & $\begin{array}{l}\text { Possibly compete } \\
\text { with AHL in } \\
\text { occupying the AHL } \\
\text { receptor }\end{array}$ & \multirow{3}{*}{-} & \multirow{3}{*}{ [74] } \\
\hline Honaucin B & & & & - & & \\
\hline \multicolumn{2}{|l|}{ Honaucin C } & & & & & \\
\hline Malyngolide & $\begin{array}{l}\text { Cyanobacterium } \\
\text { Lyngbya majuscula }\end{array}$ & $\begin{array}{l}\text { Indian River Lagoon, } \\
\text { USA }\end{array}$ & sub-MIC: $3.57-57 \mu \mathrm{M}$ & $\begin{array}{l}\text { Possibly inhibit QS by } \\
\text { reducing or partially } \\
\text { blocking the } \\
\text { expression of lasR }\end{array}$ & $\begin{array}{l}\text { Inhibit Las QS-dependent production } \\
\text { of elastase by Pseudomonas aeruginosa, } \\
\text { and possibly help the cyanobacterium } \\
\text { to control growth of heterotrophic } \\
\text { bacteria }\end{array}$ & [75] \\
\hline Benzyl benzoate & Oceanobacillus sp. & Marine environment & $\begin{array}{l}\text { sub-MIC: } \mu \mathrm{g} / \mathrm{mL} \\
\text { grade }\end{array}$ & - & $\begin{array}{l}\text { Inhibit pyocyanin production, elastase } \\
\text { activity and biofilm formation of } \\
\text { Pseudomonas aeruginosa }\end{array}$ & [65] \\
\hline 13Z-Octadecenal & $\begin{array}{l}\text { Streptomyces } \\
\text { griseoincarnatus }\end{array}$ & $\begin{array}{l}\text { Marine sponge } \\
\text { Callyspongia sp. from } \\
\text { Gulf of Mannar, India }\end{array}$ & - & $\begin{array}{l}\text { Bind to AHL synthase } \\
\text { LasI of Pseudomonas } \\
\text { aeruginosa }\end{array}$ & $\begin{array}{l}\text { Possibly inhibit Pseudomonas aeruginosa } \\
\text { biofilm }\end{array}$ & [76] \\
\hline
\end{tabular}

Note: MIC: minimum inhibitory concentration for microorganism growth. 


\section{Small Molecule QSIs Derived from Marine Bacteria}

\subsection{Natural Small Molecule QSIs}

To date, natural small molecule QSIs of different structures and origins have been isolated and identified from a variety of marine bacteria. Structures, origins, anti-QS working concentrations, mechanisms, and effects of the small molecule QSIs are outlined in Table 1. Based on structural characteristics, small molecule QSIs could be divided into five categories, including cyclic and linear peptides, amides, fatty acids and phenol derivatives, AHL analogs, and others. From the aspects of anti-QS mechanisms, the reported QSIs might antagonize AHL, (S)-3-hydroxytridecan-4-one (CAI-1) and AIP signal molecule-mediated QS systems both in Gram-negative and Gram-positive bacteria. The working mechanisms of reported small molecule QSIs could be divided into mainly four types, including competition for receptor proteins with signal molecules, interfering in the stability of receptors, blocking the expression of signal molecule receptor protein, as well as inhibiting signal molecule synthesis by binding to AHL synthase. Certain types were newly proposed modes of action for QS inhibition and remained to be verified. It is noticeable that certain marine bacteria-derived chemical compounds might function as precursors of QSIs, such as polyhydroxy butyrates (PHB), which might be degraded by PHB depolymerase in the pathogen Vibrio. Although PHB addition in the Vibrio culture could inhibit QS, due to the insolubility of PHB in water, the degradation product $\beta$-hydroxy butyric acid might actually function as the QSI [68].

It is interesting to notice that certain suspected QSIs shared structural or functional similarities with different types of signal molecules, e.g., AHLs, AI-2 and autoinducing peptides (AIPs). For AHLs analogs, Bruns et al. mentioned $N$-Acylated amino acid methyl esters produced by marine Roseobacter group bacteria isolated from macroalgae. These compounds had structural similarities with QS signaling molecule AHLs and have antagonistic activity against other microorganisms in vicinity [77]. Phenethylamides were also indicated as AHL structural mimics and might function as QSIs by competing for receptor binding [66]. Also, certain probiotic bacteria were reported to produce AHLs which could possibly compete with different structural AHLs in other pathogens, thus inhibiting their QS regulation pathways and virulence [73]. A suspected QSI which might work as AI-2 signal molecules was also discovered. Pentadecanal, a long-chain fatty aldehyde from Antarctic marine bacterium Pseudoalteromonas haloplanktis, could suppress biofilm formation of Staphylococcus epidermidis, possibly by interference with the AI-2/QS system [78]. For AIP analogs, ngercheumicins and solonamides were found as potential QSIs sharing similar structural traits with the AIPs of S. aureus $[62,63]$. Besides the above mentioned suspected QSIs, diketopiperazines (DKPs) were also proposed as potential QSIs [53], which were previously found to serve as QS signal molecules in Burkholderia sp. These signal molecule analogs, due to their structural features or functions, might have dual functions as both QSIs and QS signal molecules. It is possible that they serve as QS signal molecules either for their producing bacteria or for other bacteria in the same community, exerting cross-species QS manipulation.

Besides above-mentioned QSIs, certain researches also isolated some suspected QSIs, of which the chemical structures or anti-QS activities were not determined or verified. Durai et al. found that marine sponge associated bacteria Alcaligenes faecalis contained an active fraction with anti-QS activity. However, the isolated substance was not yet determined as QSIs exactly [79]. Also, Clark et al. isolated several tumonoic acids from a marine cyanobacterium as possible QSIs, which showed only modest QS inhibition activities with the assay of one biosensor strain but no QS inhibition activities with another biosensor strain [80]. Ibacache-Quiroga et al. reported a biosurfactant as a potential QS inhibitor, which was produced by a marine bacterium Cobetia sp. isolated from seawater samples in intertidal coastal ponds in Chile. The biosurfactant was suspected to be a mixture of 3-hydroxy fatty acids, which could interfere with QS of a fish pathogen and repress its QS-controlled virulence gene expression. The interfering mechanism might be that the biosurfactant and AHLs form lipid aggregates [81]. In summary, natural small molecule QSIs remained to be isolated, purified, and researched for their anti-QS activities and mechanisms. To further disclose and elucidate anti-QS 
mechanisms, multiple techniques should be used, especially molecular biology and structural biology techniques, e.g., combination of molecular docking methods and dynamics simulations, as well as crystal structure analysis of the complex of QSI, signal molecule receptor, etc.

\subsection{Structural Modification of Natural Small Molecule QSIs}

Researches of natural QSIs are now faced with two problems: Firstly, extraction from marine bacteria yielded only small amounts of QSIs due to the low content of natural QSIs in marine bacterial metabolites, the loss in complicated purification procedures and the instability of the natural QSIs; Secondly, certain natural QSIs were not quite effective, even toxic to target bacteria, which greatly limited their potential applications. To solve above two problems, chemical synthesis and structural modification of natural QSIs might be an alternative choice.

In early and recent studies focusing on structural modification of QSIs from marine origins, one common target was natural furanones isolated from macroalga. Since furanones might be toxic to aquatic organisms, synthetic QSIs based on their structures have been designed and tested. A synthetic furanone derivative C-30 has been proven to enhance QS-inhibitory activity and could effectively inhibit virulence gene expression in P. aeruginosa [82]. Lactam analogs of the QS inhibitor fimbrolides-a class of halogenated furanones isolated from the red marine alga-were synthesized and proved to have QS-inhibitory activities [83]. Brominated thiophenones, sulfur analogs of furanones, were also proved as effective QSIs, however, they were found to be toxic to the tested aquatic organisms [84].

Structural modification of QSIs from marine bacteria was rarely mentioned only until recent years. Choi et al. has synthesized honaucin A (a natural QS inhibitor isolated from a marine cyanobacterium) and several derivatives using the fragment-based drug design strategy. The derivatives were designed based on alcohol unit, acid unit, and the whole structure of honaucin A. Evaluation proved that halogen substitution could effectively enhance the QS-inhibitory activity, which was dozens of times higher than that of honaucin A. Among the 23 candidates, $4^{\prime}$-bromohonaucin A seemed to be the most promising QSI [74]. Hansen et al. designed a series of lactam hybrid analogs of solonamide B (from marine Photobacterium halotolerans) and AIPs, such as S. aureus AgrC QSIs. The structural modification targeted expansion of ring size, type of side chain, amino acid substitutions and stereochemistry. The key factors in structures necessary for QS-inhibitory activity include the presence of a short fatty acid tail, the optimal tail length, all-D stereochemistry, Phe residue in the 2-position and Leu in 5-position, etc. Out of 27 analogs, five most efficient were screened out, the QS-inhibitory activities of which were also dozens of times higher than the compound before structural optimization [85]. Kwan et al. also compared the QS-inhibitory activity of lyngbyoic acid (from a marine cyanobacterium) with its structural related compounds. It was indicated that the fused cyclopropane "tag" in lyngbyoic acid, the free acid moiety, and longer alkyl chains might be crucial for the QS-inhibitory function [69]. $\mathrm{Du}$ et al. isolated several $\alpha$-pyrones (from a Streptomyces sp. derived from marine algae) without QS-inhibitory activities. However, several $-\alpha$-pyridones (pyridin-2(1H)-ones) obtained by the diversity enhanced extract method—showed QS-inhibitory activities [86]. This indicated that marine-derived natural compounds could also be considered as precursors of potential QSIs. The structures of above mentioned natural QSIs and their most promising derivatives were summarized in Figure 3.

The abundance of QS-inhibitory bacteria and natural compounds in marine environments provides us with great opportunities to create more novel and efficient QS-inhibitory compounds based on the identified natural structures. In structural modification, we should fully concern structure-activity relationships. Once the essential structural features responsible for QS-inhibitory activity are revealed, analogs of natural QSIs with high potency would be designed and synthesized more rationally. Since certain QSIs resemble the structures of signal molecules of different QS systems, as mentioned above in Section 3.1, a novel QS inhibitor design could also be performed based on the natural structures of AHLs, AI-2, AIPs, etc. Small alterations in the signal molecule structural motifs might lead to effective QS antagonists. To test the QS-inhibitory activities of the structure-modified compounds, traditional assay with QS biosensor strains and computer-aided molecular docking with the crystal 
structures of signal molecule receptors should be used in combination. The latter method could provide a high-throughput screening for effective QSIs. It could also help researchers to identify critical functional groups in the modified QSIs and explain their anti-QS mechanisms.

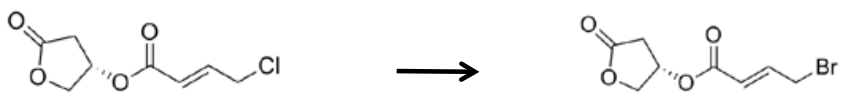

honaucin A

4'-bromohonaucin A

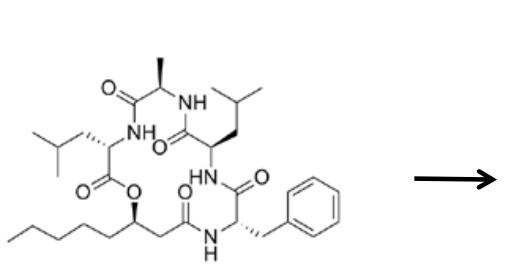

solonamide B

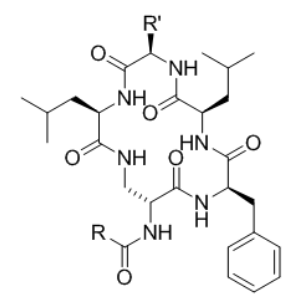

1: $\mathrm{R}=\mathrm{H}_{3} \mathrm{C}\left(\mathrm{CH}_{2}\right)_{5} ; \mathrm{R}^{\prime}=\mathrm{H}_{3} \mathrm{C}-$

2: $\mathrm{R}=\mathrm{H}_{3} \mathrm{C}\left(\mathrm{CH}_{2}\right)_{6} ; \mathrm{R}^{\prime}=\mathrm{H}_{3} \mathrm{C}-$

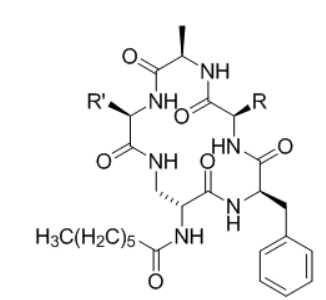

3: $\mathrm{R}=\mathrm{PhCH}_{2}-; \mathrm{R}^{\prime}=\left(\mathrm{H}_{3} \mathrm{C}\right)_{2} \mathrm{CHCH}_{2}-$

4: $\mathrm{R}=\left(\mathrm{H}_{3} \mathrm{C}\right)_{2} \mathrm{CHCH}_{2} \mathrm{CH}_{2}-; \mathrm{R}^{\prime}=\left(\mathrm{H}_{3} \mathrm{C}\right)_{2} \mathrm{CHCH}_{2}-$

5: $\mathrm{R}=\left(\mathrm{H}_{3} \mathrm{C}\right)_{2} \mathrm{CHCH}_{2}-; \mathrm{R}^{\prime}=\left(\mathrm{H}_{3} \mathrm{C}\right)_{2} \mathrm{CHCH}_{2} \mathrm{CH}_{2}-$

lactam hybrid analogues of solonamide B and AIPs

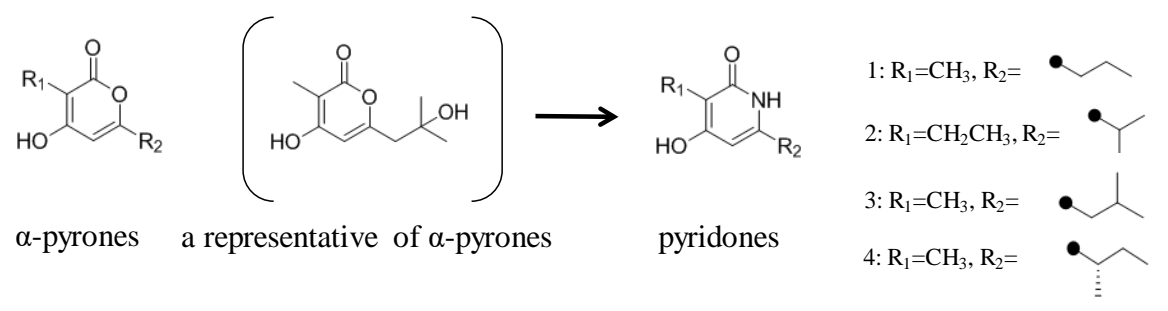

Figure 3. Structure modification of natural marine bacteria-derived QSIs/chemical compounds to obtain more potent QSIs. To the left of the arrow are natural QSIs or natural chemical compounds without QS-inhibitory activity. To the right of the arrow are novel QSIs after structure modification.

Besides chemical synthesis and structural modification, biosynthesis of QSIs might be another consideration. Study of the whole-genome sequence of the strains producing QSIs might provide insights for the clear biosynthetic routes of the inhibitors, thus facilitating more effective biosynthesis.

\section{Quorum Quenching Enzymes Derived from Marine Bacteria}

Quorum quenching activities have been reported widely in marine bacteria. For example, Romero et al. found that 85 out of 464 strains isolated from seawater could eliminate AHLs (C12-HSL), in which two strains with wide substrate spectrum were deduced to have lactonase activity. Also, a relatively high frequency of quorum quenching genes in marine metagenomes was discovered by blast [29]. Muras et al. also found a high prevalence of quorum quenching enzyme sequences in metagenomic samples in the Mediterranean Sea. They found that the relative abundance of acylase sequences increased in the deep sea while lactonase sequences seemed to distribute more averagely in different depth of seawater [38].

To date, although quorum quenching enzymes have been widely reported, these types of enzymes of marine origin have not been fully revealed in gene sequences and characteristics. Many studies only discovered marine bacteria with AHL degrading ability without purification and identification of the exact quorum quenching enzymes. Romero et al. found Tenacibaculum maritimum-a fish pathogen - could possibly produce acylase targeting C10-HSL [87]. Nithya mentioned a Bacillus pumilus isolated from Palk Bay sediments possibly having acylase activity, which could be used for effectively inhibition of QS-regulated virulence expression and biofilm formation of P. aeruginosa [88]. 
Tang et al. screened out 25 strains from flounder with wide AHL-degradation ability, 12 strains of which were indicated to have AHL lactonase activities [33]. Ghani et al. found that a Labrenzia sp. isolated from Malaysian seawater could degrade a wide range of AHLs via lactonase activity, yet the quorum quenching enzyme gene was not revealed [89]. Romero et al. screened out 15 marine bacterial strains (belonging to ten genera) that could enzymatically inactivate AHLs (C4-HSL and C12-HSL); some might have lactonase activities while others might have acylase activities [47].

Besides the above studies, some researchers identified the specific genes that encode quorum quenching enzymes. Phelan et al. found that two endospore-forming bacteria (possibly Bacillus cereus) from marine sponge have an aiiA gene encoding AHL lactonase activity [90]. Kem et al. identified a bnt $A$ gene and two genes ( $m h t A$ and $m h t B$ ) from marine bacteria Marinobacter sp. and Marinobacter nanhaiticus, respectively. These genes were homologues of acylase gene $p v d Q$ in Pseudomonas aeruginosa [91]. Gutiérrez-Barranquero et al. found a gene encoding penicillin amidase enzyme (with potential for AHL degradation) in Paracoccus sp. from a marine sponge harvested off the west coast of Ireland [92]. Kalia et al. found through genome analysis that three strains belonging to marine gammaproteobacteria possess conserved domains for AHL-lactonases and acylases [93]. Teasdale screened seven strains from various marine environments; six were isolated from marine sediments and belonged to Bacillus sp., and one from microbial mats belonged to Halobacillus sp. All have the AHL lactonase gene aiiA [37]. Rehman et al. isolated seven strains of Proteobacteria from Red Sea sediments, which could degrade AHL molecules of different acyl chain lengths and modifications. Further genome sequencing of three strains discovered AHL lactonase open reading frames (ORFs) mainly belonging to metallo- $\beta$-lactamase (MBL) superfamily and AHL acylase ORFs [48]. Interestingly, quorum quenching enzymes were also found in some atypical marine bacteria. Wong et al. isolated a P. aeruginosa strain from seawater in Malaysia. The strain had quiP and $p v d Q$ homologue gene sequences encoding AHL acylase [94,95]. Besides the homologues of the known AHL lactonases and acylases, other enzyme types for QS interference might also exist. Weiland-Bräuer et al. searched for ORFs conferring quorum quenching activity in marine Eukarya-associated bacteria isolates. The ORFs identified in Photobacterium sp., Pseudoalteromonas sp., and Vibrio parahaemolyticus encoded proteins with unknown functions or different functions from the known lactonases or acylases. The functions of these novel proteins remained to be disclosed [45].

Recently, only a few researches provided relatively in-depth and comprehensive studies of quorum quenching enzymes from marine bacteria (Table 2). As reported, AHL lactonases from bacterial origin could be mainly divided into metallo- $\beta$-lactamase (MBL) superfamily, $\alpha / \beta$ hydrolase family, phosphotriesterase (PTE) family, GDSL hydrolase family, etc., based on amino acid sequence features and relationship [96]. However, we found that $\alpha / \beta$ hydrolase family and PTE family proteins are lacking in marine bacteria-derived lactonases. For marine bacteria-derived acylases, the two listed (Table 2) belong to N-terminal nucleophile (Ntn) hydrolase family. Most of the quorum quenching enzymes have a relatively wide substrate spectrum. Tolerance to heat and wide $\mathrm{pH}$ ranges of certain enzymes indicated their promising applications in a wide range of fields.

Since only a limited amount of quorum quenching enzymes has been studied, there is still vast space for researchers to explore novel quorum quenching enzymes from marine bacteria. In several studies, it is assumed that AHL acylase might be more common than lactonase in marine bacteria $[29,33,38]$. This speculation still needs us to verify with more research results. Besides the known quorum quenching enzyme categories such as AHL lactonase and acylase, we could speculate that other enzymes types in marine bacteria might also participate in AHL degradation, utilization or interference. To determine the existence and exact functioning mechanisms of novel quorum quenching enzymes, biosensor strain assay, HPLC-MS, gene cloning, genome sequencing technologies, etc. should be utilized in combination. To facilitate the application of these enzymes, protein structure analysis and site-directed mutagenesis technologies should be applied to produce structure-modified quorum quenching enzymes with good stability and high efficiency. 
Table 2. Marine bacteria derived-quorum quenching enzymes. Categories, origins, substrate spectrums, environmental tolerance and applications.

\begin{tabular}{|c|c|c|c|c|c|c|c|c|}
\hline $\begin{array}{l}\text { Quorum } \\
\text { Quenching } \\
\text { Enzymes }\end{array}$ & $\begin{array}{l}\text { Protein Sequence } \\
\text { Accession Number }\end{array}$ & $\begin{array}{c}\text { Protein } \\
\text { Superfamily/Family }\end{array}$ & Bacteria & $\begin{array}{l}\text { Marine Origin } \\
\text { of the Bacteria }\end{array}$ & Substrate Spectrum & $\begin{array}{l}\text { Environmental } \\
\text { Tolerance }\end{array}$ & Applications & References \\
\hline $\begin{array}{l}\text { AHL lactonase } \\
\text { Aii20J }\end{array}$ & AKN24544 & Metallo- $\beta$-lactamase & $\begin{array}{l}\text { Tenacibaculum } \\
\text { sp. }\end{array}$ & $\begin{array}{l}\text { Sediment of fish } \\
\text { culture tank, } \\
\text { Spain }\end{array}$ & $\begin{array}{c}\text { AHLs (C4-HSL, C6-HSL, } \\
\text { C8-HSL, C10-HSL, C12-HSL, } \\
\text { C14-HSL, OC6-HSL, } \\
\text { OC10-HSL, OC12-HSL, } \\
\text { OC13-HSL, OC14-HSL, } \\
\text { OHC10-HSL, OHC12-HSL) }\end{array}$ & $\begin{array}{l}\text { With heat resistance } \\
\text { in cell extracts, } \\
\text { tolerance to } \\
\text { protease and wide } \\
\text { pH range 3-9 }\end{array}$ & $\begin{array}{l}\text { Quench AHL-mediated acid } \\
\text { resistance in Escherichia coli } \\
\text { (gastrointestinal pathogens) }\end{array}$ & [97] \\
\hline AHL lactonase AiiA & CAJ84442 & Metallo- $\beta$-lactamase & Bacillus cereus & $\begin{array}{c}\text { Seawater } \\
\text { samples of } \\
\text { South China Sea }\end{array}$ & OC8-HSL & - & - & [98] \\
\hline $\begin{array}{l}\text { AHL lactonase } \\
\text { MomL }\end{array}$ & AIY30473 & Metallo- $\beta$-lactamase & $\begin{array}{c}\text { Muricauda } \\
\text { olearia }\end{array}$ & $\begin{array}{l}\text { Skin mucus of } \\
\text { flounders from } \\
\text { marine fish } \\
\text { farms in China }\end{array}$ & $\begin{array}{l}\text { AHLs (C4-HSL, C6-HSL, } \\
\text { C8-HSL, OC6-HSL, OC8-HSL, } \\
\text { OC10-HSL) }\end{array}$ & $\begin{array}{l}\text { No heat resistance, } \\
\text { tolerance to } \mathrm{pH} \\
\text { range 7-11 }\end{array}$ & $\begin{array}{l}\text { Attenuate the virulence } \\
\text { (extracellular protease activity } \\
\text { and pyocyanin production) of } \\
\text { Pseudomonas aeruginosa, } \\
\text { increase the survival of } \\
\text { Caenorhabditis elegans }\end{array}$ & [99] \\
\hline $\begin{array}{c}\text { AHL lactonase } \\
\text { QsdH }\end{array}$ & $\begin{array}{l}\text { (Included in) } \\
\text { AFV15299 }\end{array}$ & GDSL hydrolase & $\begin{array}{l}\text { Pseudoalteromonas } \\
\text { byunsanensis }\end{array}$ & $\begin{array}{l}\text { Marine Culture } \\
\text { Collection of } \\
\text { China }\end{array}$ & $\begin{array}{l}\text { AHL (C4HSL, C6HSL, C8HSL, } \\
\text { C10HSL, C12HSL, C14HSL, } \\
\text { OC6-HSL, OC8-HSL) }\end{array}$ & No heat resistance & $\begin{array}{c}\text { Attenuate the plant } \\
\text { pathogenicity of Erwinia } \\
\text { carotovora }\end{array}$ & [100] \\
\hline $\begin{array}{l}\text { AHL lactonase } \\
\text { RmmL }\end{array}$ & AYM45058 & Metallo- $\beta$-lactamase & Ruegeria mobilis & $\begin{array}{c}\text { Healthy shrimp } \\
\text { larvae }\end{array}$ & $\begin{array}{l}\text { AHL (C6-HSL, C8-HSL, } \\
\text { C10-HSL, C12-HSL, OC6-HSL, } \\
\text { OC8-HSL, OC10-HSL, } \\
\text { OC12-HSL, OC14-HSL) }\end{array}$ & $\begin{array}{l}\text { No heat resistance, } \\
\text { tolerance to } \mathrm{pH} \\
\text { range 2-9 }\end{array}$ & $\begin{array}{l}\text { Reduce the production of } \\
\text { virulent factor pyocyanin by } \\
\text { Pseudomonas aeruginosa }\end{array}$ & [96] \\
\hline AHL lactonase FiaL & - & Metallo- $\beta$-lactamase & $\begin{array}{l}\text { Flaviramulus } \\
\text { ichthyoenteri }\end{array}$ & $\begin{array}{l}\text { Intestine of } \\
\text { cultured healthy } \\
\text { flounder in } \\
\text { China }\end{array}$ & $\begin{array}{c}\text { AHL (C6-HSL, C8-HSL, } \\
\text { C10-HSL, C12-HSL, C14-HSL, } \\
\text { OC6-HSL, OC8-HSL, } \\
\text { OC10-HSL, OC12-HSL, } \\
\text { OC14-HSL) }\end{array}$ & - & - & [101] \\
\hline AHL acylase MhtA & ENO13542 & Ntn-hydrolases & $\begin{array}{l}\text { Marinobacter } \\
\text { nanhaiticus }\end{array}$ & $\begin{array}{l}\text { Sediment of the } \\
\text { South China Sea }\end{array}$ & AHL (C12-HSL) & - & - & [91] \\
\hline AHL acylase PfmA & ASS36259 & Ntn hydrolase & $\begin{array}{l}\text { Pseudoalteromonas } \\
\text { flavipulchra }\end{array}$ & $\begin{array}{l}\text { Water used to } \\
\text { rear healthy } \\
\text { turbot in China }\end{array}$ & $\begin{array}{l}\text { AHL (C10-HSL, C12-HSL, } \\
\text { C14-HSL, OC12-HSL, } \\
\text { OC14-HSL, OHC14-HSL) }\end{array}$ & $\begin{array}{l}\text { No heat resistance, } \\
\text { tolerance to } \mathrm{pH} \\
\text { range 5-11 }\end{array}$ & $\begin{array}{c}\text { Reduce virulence factor } \\
\text { protease production in Vibrio } \\
\text { anguillarum, reduce protease } \\
\text { and pyocyanin in Pseudomonas } \\
\text { aeruginosa, increase survival of } \\
\text { infected Artemia }\end{array}$ & [102] \\
\hline
\end{tabular}

Note: no heat resistance means that the enzyme activity drops at temperature higher than $50{ }^{\circ} \mathrm{C}$. 


\section{Potential Application Perspectives of QSIs or QSI-Producing Bacteria}

The emergence of multidrug-resistant pathogens requires the researchers to find new therapeutic methods. QS interference might become a novel antimicrobial therapy based on non-antibiotic strategy and an attractive alternative to traditional chemical drugs and antibiotics. Therefore, QSIs have aroused increasing attention. As mentioned above, QSIs could either be small molecule chemical compounds or quorum quenching enzymes, both interfering with bacterial QS systems. Either the purified QSIs or probiotic bacteria with QS-inhibitory activities have the potential for applications in various fields, including food preservation, aquaculture, human healthcare, ecological protection, etc., by controlling QS-mediated food spoilage and inhibiting QS-mediated biofilm formation and virulence of pathogens.

To date, applications of marine bacteria-derived QSIs are few and limited. As we summarized in Table 1, marine-derived small molecule QSIs have mainly been used to inhibit biofilm formation and QS-regulated virulence expression in P. aeruginosa, S. aureus, Vibrio sp., and uropathogen S. marcescens, to further reduce the toxicity of pathogens. Based on current researches, these small molecule QSIs are promising in curing diseases of human beings and aquatic animals. As for the reported quorum quenching enzymes (Table 2), besides targeting P. aeruginosa and Vibrio sp., they were used to quench virulence of gastrointestinal pathogens (e.g., E. coli), plant pathogen E. carotovora, etc., indicating that they might be applied in human healthcare, animal culture, aquaculture and crop cultivation.

A combinational therapy of potential marine bacteria-derived QSIs and traditional antibiotics was also focused. The crude extract of a Pseudoalteromonas sp. with QS-inhibitory activity was used in combination with tobramycin against P. aeruginosa [43]. Extracts of a marine-derived Rhizobium sp. with QS-inhibitory activity were used in conjunction with kanamycin against $P$. aeruginosa [55]. Phenol, 2,4-bis(1,1-dimethylethyl) — a potential small molecule QS inhibitor of marine bacterial origin—was used synergistically with gentamicin against the uropathogen S. marcescens [72]. Compared with usage of antibiotics alone, the combination therapy could effectively increase the antimicrobial efficiency of conventional antibiotics. This combined treatment strategy, which might eradicate pathogenic infections more effectively in an early stage, is hopeful to be developed and applied in treatments of various diseases.

Besides the usage of QSIs as therapeutic agents or drugs, production of antibacterial coatings based on natural or modified QSIs seems to be another promising application field. Immobilization of furanone derivatives on polymer materials has been studied to make antibacterial medical devices, which gives us inspirations that marine bacteria-derived QSIs could also be used in medical applications to produce aseptic or antibacterial materials for disease treatments [103].

\section{Concluding Remarks}

The QS interference capabilities of marine bacteria cannot be underestimated, which are realized through QSIs, mainly including small molecules and quorum quenching enzymes. Interestingly, the origins, characteristics, and working mechanisms of QSIs are quite different. For many discovered QSIs, the latter two aspects are still unsolved mysteries. Due to the microbial diversity in the marine environment and the antimicrobial activities of QSIs, marine bacteria with QS-inhibitory activities and potential QSIs remain to be explored. In the future studies, besides large-scale screening of QS-inhibitory bacteria and discovery of QSIs, QS antagonistic mechanisms should be more effectively targeted and elucidated using combined methods and technologies, especially those at cellular and molecular levels. Also, to realize the practical applications of QSIs, their toxic effects against human beings, animals or plants should be assessed more comprehensively with multiple approaches. Only with absolute security, QSIs could truly realize their value and be put into production of antimicrobial agents or materials for disease prevention and treatments.

Funding: This work was supported by the Young Science and Technology Star Project of Dalian, China [grant number 2017RQ150].

Conflicts of Interest: The authors declare no conflict of interest. 


\section{References}

1. Miller, M.B.; Bassler, B.L. Quorum sensing in bacteria. Annu. Rev. Microbiol. 2001, 55, 165-199. [CrossRef]

2. Jayaraman, A.; Wood, T.K. Bacterial quorum sensing: Signals, circuits, and implications for biofilms and disease. Annu. Rev. Biomed. Eng. 2008, 10, 145-167. [CrossRef]

3. Boyer, M.; Wisniewski-Dye, F. Cell-cell signalling in bacteria: Not simply a matter of quorum. FEMS Microbiol. Ecol. 2009, 70, 1-19. [CrossRef] [PubMed]

4. Di Cagno, R.; De Angelis, M.; Calasso, M.; Gobbetti, M. Proteomics of the bacterial cross-talk by quorum sensing. J. Proteomics 2011, 74, 19-34. [CrossRef] [PubMed]

5. Zhao, J.; Chen, M.; Quan, C.; Fan, S. Mechanisms of quorum sensing and strategies for quorum sensing disruption in aquaculture pathogens. J. Fish Dis. 2014, 38, 771-786. [CrossRef]

6. Turkina, M.V.; Vikström, E. Bacteria-host crosstalk: Sensing of the quorum in the context of Pseudomonas aeruginosa Infections. J. Innate Immun. 2018, 11, 1-17. [CrossRef]

7. Le, K.Y.; Otto, M. Quorum-sensing regulation in staphylococci-an overview. Front. Microbiol. 2015, 6, 1174. [CrossRef]

8. Kalia, V.C.; Purohit, H.J. Quenching the quorum sensing system: Potential antibacterial drug targets. Crit. Rev. Microbiol. 2011, 37, 121-140. [CrossRef]

9. Chen, F.; Gao, Y.; Chen, X.; Yu, Z.; Li, X. Quorum quenching enzymes and their application in degrading signal molecules to block quorum sensing-dependent infection. Int. J. Mol. Sci. 2013, 14, 17477-17500. [CrossRef]

10. Defoirdt, T.; Boon, N.; Bossier, P.; Verstraete, W. Disruption of bacterial quorum sensing: An unexplored strategy to fight infections in aquaculture. Aquaculture 2004, 240, 69-88. [CrossRef]

11. Lade, H.; Paul, D.; Kweon, J.H. Quorum quenching mediated approaches for control of membrane biofouling. Int. J. Biol. Sci. 2014, 10, 547-562. [CrossRef] [PubMed]

12. Kalia, V.C. Quorum sensing inhibitors: An overview. Biotechnol. Adv. 2013, 31, 224-245. [CrossRef]

13. Defoirdt, T.; Brackman, G.; Coenye, T. Quorum sensing inhibitors: How strong is the evidence? Trends Microbiol. 2013, 21, 619-624. [CrossRef]

14. Dong, Y.H.; Zhang, L.H. Quorum sensing and quorum-quenching enzymes. J. Microbiol. 2005, 43, $101-109$.

15. Czajkowski, R.; Jafra, S. Quenching of acyl-homoserine lactone-dependent quorum sensing by enzymatic disruption of signal molecules. Acta Biochimica Polonica 2009, 56, 1-16. [CrossRef]

16. Fetzner, S. Quorum quenching enzymes. J. Biotechnol. 2015, 201, 2-14. [CrossRef]

17. Tang, K.; Zhang, X.H. Quorum quenching agents: resources for antivirulence therapy. Mar. Drugs 2014, 12, 3245-3282. [CrossRef] [PubMed]

18. Delago, A.; Mandabi, A.; Meijler, M.M. Natural quorum sensing inhibitors-small molecules, big messages. Isr. J. Chem. 2015, 56, 310-320. [CrossRef]

19. Ta, C.A.K.; Arnason, J.T. Mini review of phytochemicals and plant taxa with activity as microbial biofilm and quorum sensing Inhibitors. Molecules 2016, 21, 29. [CrossRef] [PubMed]

20. Das, R.; Mehta, D.K. Microbial biofilm and quorum sensing inhibition: endowment of medicinal plants to combat multidrug-resistant bacteria. Curr. Drug Targets 2018, 19, 1916-1932. [CrossRef]

21. Skindersoe, M.E.; Ettinger-Epstein, P.; Rasmussen, T.B.; Bjarnsholt, T.; de Nys, R.; Givskov, M. Quorum sensing antagonism from marine organisms. Mar. Biotechnol. 2007, 10, 56-63. [CrossRef]

22. Natrah, F.M.I.; Defoirdt, T.; Sorgeloos, P.; Bossier, P. Disruption of bacterial cell-to-cell communication by marine organisms and its relevance to aquaculture. Mar. Biotechnol. 2011, 13, 109-126. [CrossRef]

23. Wietz, M.; Duncan, K.; Patin, N.V.; Jensen, P.R. Antagonistic interactions mediated by marine bacteria: The role of small molecules. J. Chem. Ecol. 2013, 39, 879-891. [CrossRef] [PubMed]

24. Zhang, M.; Wang, M.; Zhu, X.; Yu, W.; Gong, Q. Equisetin as potential quorum sensing inhibitor of Pseudomonas aeruginosa. Biotechnol. Lett. 2018, 40, 865-870. [CrossRef] [PubMed]

25. Reen, F.J.; Gutiérrez-Barranquero, J.A.; Dobson, A.D.; Adams, C.; O'Gara, F. Emerging concepts promising new horizons for marine biodiscovery and synthetic biology. Mar. Drugs 2015, 13, 2924-2954. [CrossRef]

26. Costantino, V.; Della Sala, G.; Saurav, K.; Teta, R.; Bar-Shalom, R.; Mangoni, A.; Steindler, L. Plakofuranolactone as a quorum quenching agent from the Indonesian sponge Plakortis cf. lita. Mar. Drugs 2017, 15, 59. [CrossRef] [PubMed] 
27. Heo, Y.M.; Kim, K.; Ryu, S.M.; Kwon, S.L.; Park, M.Y.; Kang, J.E.; Hong, J.H.; Lim, Y.W.; Kim, C.; Kim, B.S.; et al. Diversity and ecology of marine algicolous Arthrinium species as a source of bioactive natural products. Mar. Drugs 2018, 16, 508. [CrossRef] [PubMed]

28. Chen, J.; Wang, B.; Lu, Y.; Guo, Y.; Sun, J.; Wei, B.; Zhang, H.; Wang, H. Quorum sensing inhibitors from marine microorganisms and their synthetic derivatives. Mar. Drugs 2019, 17, 80. [CrossRef]

29. Romero, M.; Martin-Cuadrado, A.B.; Otero, A. Determination of whether quorum quenching is a common activity in marine bacteria by analysis of cultivable bacteria and metagenomic sequences. Appl. Environ. Microb. 2012, 78, 6345-6348. [CrossRef] [PubMed]

30. Linthorne, J.S.; Chang, B.J.; Flematti, G.R.; Ghisalberti, E.L.; Sutton, D.C. A direct pre-screen for marine bacteria producing compounds inhibiting quorum sensing reveals diverse planktonic bacteria that are bioactive. Mar. Biotechnol. 2014, 17, 33-42. [CrossRef] [PubMed]

31. Ma, Z.P.; Song, Y.; Cai, Z.H.; Lin, Z.J.; Lin, G.H.; Wang, Y.; Zhou, J. Anti-quorum sensing activities of selected coral symbiotic bacterial extracts from the South China Sea. Front. Cell Infect. Microbiol. 2018, 8, 144. [CrossRef] [PubMed]

32. Naik, D.N.; Wahidullah, S.; Meena, R.M. Attenuation of Pseudomonas aeruginosa virulence by marine invertebrate-derived Streptomyces sp. Lett. Appl. Microbiol. 2013, 56, 197-207. [CrossRef]

33. Tang, K.; Zhang, Y.; Yu, M.; Shi, X.; Coenye, T.; Bossier, P.; Zhang, X.H. Evaluation of a new high-throughput method for identifying quorum quenching bacteria. Sci. Rep. 2013, 3, 2935. [CrossRef]

34. Golberg, K.; Pavlov, V.; Marks, R.S.; Kushmaro, A. Coral-associated bacteria, quorum sensing disrupters, and the regulation of biofouling. Biofouling 2013, 29, 669-682. [CrossRef] [PubMed]

35. Gutiérrez-Barranquero, J.A.; Reen, F.J.; Parages, M.L.; McCarthy, R.; Dobson, A.D.W.; O'Gara, F. Disruption of $\mathrm{N}$-acyl-homoserine lactone-specific signalling and virulence in clinical pathogens by marine sponge bacteria. Microb. Biotechnol. 2017. [CrossRef]

36. Yaniv, K.; Golberg, K.; Kramarsky-Winter, E.; Marks, R.; Pushkarev, A.; Béjà, O.; Kushmaro, A. Functional marine metagenomic screening for anti-quorum sensing and anti-biofilm activity. Biofouling 2016, 33, 1-13. [CrossRef]

37. Teasdale, M.E.; Donovan, K.A.; Forschner-Dancause, S.R.; Rowley, D.C. Gram-positive marine bacteria as a potential resource for the discovery of quorum sensing inhibitors. Mar. Biotechnol. 2011, 13, 722-732. [CrossRef]

38. Muras, A.; López-Pérez, M.; Mayer, C.; Parga, A.; Amaro-Blanco, J.; Otero, A. High Prevalence of quorum-sensing and quorum-quenching activity among cultivable bacteria and metagenomic sequences in the Mediterranean Sea. Genes 2018, 9, 100. [CrossRef]

39. Weiland-Bräuer, N.; Kisch, M.J.; Pinnow, N.; Liese, A.; Schmitz, R.A. Highly Effective inhibition of biofilm formation by the first metagenome-derived AI-2 quenching enzyme. Front. Microbiol. 2016, 7, 1098. [CrossRef]

40. Saurav, K.; Bar-Shalom, R.; Haber, M.; Burgsdorf, I.; Oliviero, G.; Costantino, V.; Morgenstern, D.; Steindler, L. In search of alternative antibiotic drugs: Quorum-quenching activity in sponges and their bacterial isolates. Front. Microbiol. 2016, 7, 416. [CrossRef]

41. Ong, J.F.M.; Goh, H.C.; Lim, S.C.; Pang, L.M.; Chin, J.S.F.; Tan, K.S.; Liang, Z.X.; Yang, L.; Glukhov, E.; Gerwick, W.H.; Tan, L.K. Integrated genomic and metabolomic approach to the discovery of potential anti-quorum sensing natural products from microbes associated with marine samples from Singapore. Mar. Drugs 2019, 17, 72. [CrossRef] [PubMed]

42. Nithya, C.; Begum, M.F.; Pandian, S.K. Marine bacterial isolates inhibit biofilm formation and disrupt mature biofilms of Pseudomonas aeruginosa PAO1. Appl. Microbiol. Biotechnol. 2010, 88, 341-358. [CrossRef]

43. Busetti, A.; Shaw, G.; Megaw, J.; Gorman, S.P.; Maggs, C.A.; Gilmore, B.F. Marine-derived quorum-sensing inhibitory activities enhance the antibacterial efficacy of tobramycin against Pseudomonas aeruginosa. Mar. Drugs 2015, 13, 1-28. [CrossRef] [PubMed]

44. Torres, M.; Romero, M.; Prado, S.; Dubert, J.; Tahrioui, A.; Otero, A.; Llamas, I. N-acylhomoserine lactone-degrading bacteria isolated from hatchery bivalve larval cultures. Microbiol. Res. 2013, 168, 547-554. [CrossRef] [PubMed]

45. Weiland-Bräuer, N.; Pinnow, N.; Schmitz, R.A. Novel reporter for identification of interference with acyl homoserine lactone and autoinducer-2 quorum sensing. Appl. Environ. Microb. 2015, 81, 1477-1489. [CrossRef] 
46. Kanagasabhapathy, M.; Yamazaki, G.; Ishida, A.; Sasaki, H.; Nagata, S. Presence of quorum-sensing inhibitor-like compounds from bacteria isolated from the brown alga Colpomenia sinuosa. Lett. Appl. Microbiol. 2009, 49, 573-579. [CrossRef] [PubMed]

47. Romero, M.; Martin-Cuadrado, A.B.; Roca-Rivada, A.; Cabello, A.M.; Otero, A. Quorum quenching in cultivable bacteria from dense marine coastal microbial communities. FEMS Microbiol. Ecol. 2010, 75, 205-217. [CrossRef]

48. Rehman, Z.U.; Leiknes, T. Quorum-quenching bacteria isolated from Red Sea sediments reduce biofilm formation by Pseudomonas aeruginosa. Front. Microbiol. 2018, 9, 1354. [CrossRef] [PubMed]

49. Martinez-Matamoros, D.; Laiton Fonseca, M.; Duque, C.; RAMOS, F.A.; Castellanos, L. Screening of marine bacterial strains as source of quorum sensing inhibitors (QSI): First chemical study of Oceanobacillus profundus (RKHC-62B). VITAE 2016, 23, 30-47. [CrossRef]

50. Thenmozhi, R.; Nithyanand, P.; Rathna, J.; Pandian, S.K. Antibiofilm activity of coral-associated bacteria against different clinical M serotypes of Streptococcus pyogenes. FEMS Immunol. Med. Microbiol. 2009, 57, 284-294. [CrossRef]

51. Musthafa, K.S.; Saroja, V.; Pandian, S.K.; Ravi, A.V. Antipathogenic potential of marine Bacillus sp. SS4 on $\mathrm{N}$-acyl-homoserine-lactone-mediatedvirulence factors production in Pseudomonas aeruginosa (PAO1). J. Biosci. 2011, 36, 55-67. [CrossRef]

52. You, J.; Xue, X.; Cao, L.; Lu, X.; Wang, J.; Zhang, L.; Zhou, S. Inhibition of Vibrio biofilm formation by a marine actinomycete strain A66. Appl. Microbiol. Biotechnol. 2007, 76, 1137-1144. [CrossRef] [PubMed]

53. Abed, R.M.M.; Dobretsov, S.; Al-Fori, M.; Gunasekera, S.P.; Sudesh, K.; Paul, V.J. Quorum-sensing inhibitory compounds from extremophilic microorganisms isolated from a hypersaline cyanobacterial mat. J. Ind. Microbiol. Biotechnol. 2013, 40, 759-772. [CrossRef]

54. Younis, K.M.; Usup, G.; Ahmad, A. Secondary metabolites produced by marine streptomyces as antibiofilm and quorum-sensing inhibitor of uropathogen Proteus mirabilis. Environ. Sci. Pollut. Res. 2015, 23, 4756-4767. [CrossRef]

55. Chang, H.; Zhou, J.; Zhu, X.; Yu, S.; Chen, L.; Jin, H.; Cai, Z. Strain identification and quorum sensing inhibition characterization of marine-derived Rhizobium sp. NAO1. Roy. Soc. Open Sci. 2017, 4, 170025. [CrossRef]

56. Tinh, N.T.N.; Asanka Gunasekara, R.A.; Boon, N.; Dierckens, K.; Sorgeloos, P.; Bossier, P. N-acyl homoserine lactone-degrading microbial enrichment cultures isolated from Penaeus vannamei shrimp gut and their probiotic properties in Brachionus plicatilis cultures. FEMS Microbiol. Ecol. 2007, 62, 45-53. [CrossRef] [PubMed]

57. Tinh, N.T.N.; Yen, V.H.N.; Dierckens, K.; Sorgeloos, P.; Bossier, P. An acyl homoserine lactone-degrading microbial community improves the survival of first-feeding turbot larvae (Scophthalmus maximus L.). Aquaculture 2008, 285, 56-62. [CrossRef]

58. Cam, D.T.V.; Nhan, D.T.; Ceuppens, S.; Hao, N.V.; Dierckens, K.; Wille, M.; Sorgeloos, P.; Bossier, P. Effect of $\mathrm{N}$-acyl homoserine lactone-degrading enrichment cultures on Macrobrachium rosenbergii larviculture. Aquaculture 2009, 294, 5-13. [CrossRef]

59. Sun, S.; Dai, X.; Sun, J.; Bu, X.; Weng, C.; Li, H.; Zhu, H. A diketopiperazine factor from Rheinheimera aquimaris QSI02 exhibits anti-quorum sensing activity. Sci. Rep. 2016, 6, 39637. [CrossRef] [PubMed]

60. Gowrishankar, S.; Poornima, B.; Pandian, S.K. Inhibitory efficacy of cyclo (L-leucyl-L-prolyl) from mangrove rhizosphere bacterium-Bacillus amyloliquefaciens (MMS-50) toward cariogenic properties of Streptococcus mutans. Res. Microbiol. 2014, 165, 278-289. [CrossRef] [PubMed]

61. Gowrishankar, S.; Pandian, S.K.; Balasubramaniam, B.; Balamurugan, K. Quorum quelling efficacy of marine cyclic dipeptide -cyclo(L-leucyl-L-prolyl) against the uropathogen Serratia marcescens. Food Chem. Toxicol. 2019, 123, 326-336. [CrossRef]

62. Kjaerulff, L.; Nielsen, A.; Mansson, M.; Gram, L.; Larsen, T.O.; Ingmer, H.; Gotfredsen, C.H. Identification of four new agr quorum sensing-interfering cyclodepsipeptides from a marine photobacterium. Mar. Drugs 2013, 11, 5051-5062. [CrossRef]

63. Mansson, M.; Nielsen, A.; Kjærulff, L.; Gotfredsen, C.H.; Wietz, M.; Ingmer, H.; Gram, L.; Larsen, T.O. Inhibition of virulence gene expression in Staphylococcus aureus by novel depsipeptides from a marine photobacterium. Mar. Drugs 2011, 9, 2537-2552. [CrossRef] 
64. Nielsen, A.; Månsson, M.; Bojer, M.S.; Gram, L.; Larsen, T.O.; Novick, R.; Frees, D.; Frøkiær, H.; Ingmer, H. Solonamide B inhibits quorum sensing and reduces Staphylococcus aureus mediated killing of human neutrophils. PLoS ONE 2014, 9, e84992. [CrossRef]

65. Chen, X.; Chen, J.; Yan, Y.; Chen, S.; Xu, X.; Zhang, H.; Wang, H. Quorum sensing inhibitors from marine bacteria Oceanobacillus sp. XC22919. Nat. Prod. Res. 2018, 12, 1-5. [CrossRef]

66. Teasdale, M.E.; Liu, J.; Wallace, J.; Akhlaghi, F.; Rowley, D.C. Secondary metabolites produced by the marine bacterium Halobacillus salinus that inhibit quorum sensing-controlled phenotypes in gram-negative bacteria. Appl. Environmen. Microb. 2009, 75, 567-572. [CrossRef]

67. Kwan, J.C.; Teplitski, M.; Gunasekera, S.P.; Paul, V.J.; Luesch, H. Isolation and biological evaluation of 8-epi-malyngamide C from the Floridian marine cyanobacterium Lyngbya majuscula. J. Nat. Prod. 2010, 73, 463-466. [CrossRef]

68. Kiran, G.S.; Priyadharshini, S.; Dobson, A.D.W.; Gnanamani, E.; Selvin, J. Degradation intermediates of polyhydroxy butyrate inhibits phenotypic expression of virulence factors and biofilm formation in luminescent Vibrio sp. PUGSK8. NPJ Biofilms Microb. 2016, 2, 16002. [CrossRef]

69. Kwan, J.C.; Meickle, T.; Ladwa, D.; Teplitski, M.; Paul, V.; Luesch, H. Lyngbyoic acid, a "tagged” fatty acid from a marine cyanobacterium, disrupts quorum sensing in Pseudomonas aeruginosa. Mol. BioSyst. 2011, 7, 1205-1216. [CrossRef]

70. Meyer, J.L.; Gunasekera, S.P.; Scott, R.M.; Paul, V.J.; Teplitski, M. Microbiome shifts and the inhibition of quorum sensing by Black Band Disease cyanobacteria. ISME J. 2015, 10, 1204-1216. [CrossRef]

71. Montaser, R.; Paul, V.J.; Luesch, H. Modular strategies for structure and function employed by marine cyanobacteria: Characterization and synthesis of pitinoic acids. Org. Lett. 2013, 15, 4050-4053. [CrossRef] [PubMed]

72. Padmavathi, A.R.; Abinaya, B.; Pandian, S.K. henol, 2,4-bis(1,1-dimethylethyl) of marine bacterial origin inhibits quorum sensing mediated biofilm formation in the uropathogen Serratia marcescens. Biofouling 2014, 30, 1111-1122. [CrossRef]

73. Zhao, W.; Yuan, T.; Piva, C.; Spinard, E.J.; Schuttert, C.; Rowley, D.C.; Nelson, D.R. The probiotic bacterium Phaeobacter inhibens downregulates virulence factor transcription in the shellfish pathogen, Vibrio coralliilyticus, by $N$-acyl homoserine lactone production. Appl. Environ. Microb. 2019, 85, e01545-18. [CrossRef]

74. Choi, H.; Mascuch, S.J.; Villa, F.A.; Byrum, T.; Teasdale, M.E.; Smith, J.E.; Preskitt, L.B.; Rowley, D.C.; Gerwick, L.; Gerwick, W.H. Honaucins A-C, potent inhibitors of inflammation and bacterial quorum sensing: synthetic derivatives and structure-activity relationships. Chem. Biol. 2012, 19, 589-598. [CrossRef]

75. Dobretsov, S.; Teplitski, M.; Alagely, A.; Gunasekera, S.P.; Paul, V.J. Malyngolide from the cyanobacterium Lyngbya majuscula interferes with quorum sensing circuitry. Env. Microbiol. Rep. 2010, 2, 739-744. [CrossRef]

76. Kamarudheen, N.; Rao, K.V.B. Fatty acyl compounds from marine Streptomyces griseoincarnatus strain HK12 against two major biofilm forming nosocomial pathogens; an in vitro and in silico approach. Microb. Pathogenesis 2019, 127, 121-130. [CrossRef] [PubMed]

77. Bruns, H.; Ziesche, L.; Taniwal, N.K.; Wolter, L.; Brinkhoff, T.; Herrmann, J.; Müller, R.; Schulz, S. N-acylated amino acid methyl esters from marine Roseobacter group bacteria. Beilstein J. Org. Chem. 2018, 14, $2964-2973$. [CrossRef]

78. Casillo, A.; Papa, R.; Ricciardelli, A.; Sannino, F.; Ziaco, M.; Tilotta, M.; Selan, L.; Marino, G.; Corsaro, M.M.; Tutino, M.L.; et al. Anti-biofilm activity of a long-chain fatty aldehyde from Antarctic Pseudoalteromonas haloplanktis TAC125 against Staphylococcus epidermidis Biofilm. Front. Cell. Infect. Mi. 2017, 7, 46. [CrossRef]

79. Durai, S.; Vigneshwari, L.; Balamurugan, K. Caenorhabditis elegans-based in vivo screening of bioactives from marine sponge-associated bacteria against Vibrio alginolyticus. J. Appl. Microbiol. 2013, 115, 1329-1342. [CrossRef] [PubMed]

80. Clark, B.R.; Engene, N.; Teasdale, M.E.; Rowley, D.C.; Matainaho, T.; Valeriote, F.A.; Gerwick, W.H. Natural Products Chemistry and Taxonomy of the Marine Cyanobacterium Blennothrix cantharidosmum. J. Nat. Prod. 2008, 71, 1530-1537. [CrossRef]

81. Ibacache-Quiroga, C.; Ojeda, J.; Espinoza-Vergara, G.; Olivero, P.; Cuellar, M.; Dinamarca, M.A. The hydrocarbon-degrading marine bacterium Cobetia sp. strain MM1IDA2H-1 produces a biosurfactant that interferes with quorum sensing of fish pathogens by signal hijacking. Microb. Biotechnol. 2013, 6, 394-405. [CrossRef] 
82. Hentzer, M.; Wu, H.; Andersen, J.B.; Riedel, K.; Rasmussen, T.B.; Bagge, N.; Kumar, N.; Schembri, M.A.; Song, Z.; Kristoffersen, P.; et al. Attenuation of Pseudomonas aeruginosa virulence by quorum sensing inhibitors. EMBO J. 2003, 22, 3803-3815. [CrossRef] [PubMed]

83. Goh, W.K.; Gardner, C.R.; Chandra Sekhar, K.V.G.; Biswas, N.N.; Nizalapur, S.; Rice, S.A.; Wilcox, M.; Black, D.S.; Kumar, N. Synthesis, quorum sensing inhibition and docking studies of 1,5-dihydropyrrol-2-ones. Bioorg. Med. Chem. 2015, 23, 7366-7377. [CrossRef] [PubMed]

84. Lillicrap, A.; Macken, A.; Wennberg, A.C.; Grung, M.; Rundberget, J.T.; Fredriksen, L.; Scheie, A.A.; Benneche, T.; d'Auriac, M.A. Environmental fate and effects of novel quorum sensing inhibitors that can control biofilm formation. Chemosphere 2016, 164, 52-58. [CrossRef] [PubMed]

85. Hansen, A.M.; Peng, P.; Baldry, M.; Perez-Gassol, I.; Christensen, S.B.; Vinther, J.M.O.; Ingmer, H.; Franzyk, H. Lactam hybrid analogues of solonamide B and autoinducing peptides as potent S. aureus AgrC antagonists. Eur. J. Med. Chem. 2018, 152, 370-376. [CrossRef]

86. Du, Y.; Sun, J.; Gong, Q.; Wang, Y.; Fu, P.; Zhu, W. New $\alpha$-Pyridones with quorum-sensing inhibitory activity from diversity-enhanced extracts of a Streptomyces sp. derived from marine algae. J. Agric. Food Chem. 2018, 66, 1807-1812. [CrossRef] [PubMed]

87. Romero, M.; Avendaño-Herrera, R.; Magariños, B.; Cámara, M.; Otero, A. Acylhomoserine lactone production and degradation by the fish pathogen Tenacibaculum maritimum, a member of the Cytophaga-FlavobacteriumBacteroides (CFB) group. FEMS Microbiol. Lett. 2010, 304, 131-139. [CrossRef] [PubMed]

88. Nithya, C.; Aravindraja, C.; Pandian, S.K. Bacillus pumilus of Palk Bay origin inhibits quorum-sensing-mediated virulence factors in Gram-negative bacteria. Res. Microbiol. 2010, 161, $293-304$. [CrossRef] [PubMed]

89. Ghani, N.A.; Norizan, S.N.M.; Chan, X.Y.; Yin, W.F.; Chan, K.G. Labrenzia sp. BM1: A quorum quenching bacterium that degrades $\mathrm{N}$-acyl homoserine lactones via lactonase activity. Sensors 2014, 14, 11760-11769. [CrossRef]

90. Phelan, R.W.; O’Halloran, J.A.; Kennedy, J.; Morrissey, J.P.; Dobson, A.D.W.; O'Gara, F.; Barbosa, T.M. Diversity and bioactive potential of endospore-forming bacteria cultured from the marine sponge Haliclona simulans. J. Appl. Microbiol. 2012, 112, 65-78. [CrossRef] [PubMed]

91. Kem, M.P.; Naka, H.; Iinishi, A.; Haygood, M.G.; Butler, A. Fatty acid hydrolysis of acyl marinobactin siderophores by Marinobacter Acylases. Biochemistry 2015, 54, 744-752. [CrossRef]

92. Gutiérrez-Barranquero, J.A.; Parages, M.L.; Dobson, A.D.W.; Reen, F.J.; O'Gara, F. Genome sequence of Paracoccus sp. JM45, a bacterial strain isolated from a marine sponge with a dual quorum sensing inhibition activity. Microbiol. Resour. Announc. 2019, 8, e01496-18. [CrossRef]

93. Kalia, V.C.; Raju, S.C.; Purohit, H.J. Genomic analysis reveals versatile organisms for quorum quenching enzymes: acyl-homoserine lactone-acylase and -lactonase. Open Microbiol. J. 2011, 5, 1-13. [CrossRef]

94. Wong, C.S.; Yin, W.F.; Choo, Y.M.; Sam, C.K.; Koh, CL.; Chan, K.G. Coexistence of quorum-quenching and quorum-sensing in tropical marine Pseudomonas aeruginosa strain MW3A. World J. Microbiol. Biotechnol. 2012, 28, 453-461. [CrossRef] [PubMed]

95. Chan, K.G.; Wong, C.S.; Yin, W.F.; Chan, X.Y. Draft genome sequence of quorum-sensing and quorum-quenching Pseudomonas aeruginosa strain MW3a. Genome Announc. 2014, 2, e00258-14. [CrossRef] [PubMed]

96. Cai, X.; Yu, M.; Shan, H.; Tian, X.; Zheng, Y.; Xue, C.; Zhang, X.H. Characterization of a novel N-Acylhomoserine Lactonase RmmL from Ruegeria mobilis YJ3. Mar. Drugs 2018, 16, 370. [CrossRef]

97. Mayer, C.; Romero, M.; Muras, A.; Otero, A. Aii20J, a wide-spectrum thermostable N-acylhomoserine lactonase from the marine bacterium Tenacibaculum sp. 20J, can quench AHL-mediated acid resistance in Escherichia coli. Appl. Microbiol. Biotechnol. 2015, 99, 9523-9539. [CrossRef]

98. Lu, X.; Yuan, Y.; Xue, X.L.; Zhang, G.P.; Zhou, S.N. Identification of the critical role of Tyr-194 in the catalytic activity of a novel N-acyl-homoserine lactonase from marine Bacillus cereus strain Y2. Curr. Microbiol. 2006, 53, 346-350. [CrossRef]

99. Tang, K.; Su, Y.; Brackman, G.; Cui, F.; Zhang, Y.; Shi, X.; Coenye, T.; Zhang, X.H. MomL, a novel marine-derived $\mathrm{N}$-acyl homoserine lactonase from Muricauda olearia. Appl. Environ. Microbiol. 2015, 81, 774-782. [CrossRef] [PubMed]

100. Huang, W.; Lin, Y.; Yi, S.; Liu, P.; Shen, J.; Shao, Z.; Liu, Z. QsdH, a novel AHL lactonase in the RND-type inner membrane of marine Pseudoalteromonas byunsanensis strain 1A01261. PLoS ONE 2012, 7, e46587. [CrossRef] 
101. Zhang, Y.; Liu, J.; Tang, K.; Yu, M.; Coenye, T.; Zhang, X.-H. Genome analysis of Flaviramulus ichthyoenteri Th78T in the family Flavobacteriaceae: Insights into its quorum quenching property and potential roles in fish intestine. BMC Genom. 2015, 16, 38. [CrossRef] [PubMed]

102. Liu, N.; Yu, M.; Zhao, Y.; Cheng, J.; An, K.; Zhang, X.H. PfmA, a novel quorum-quenching N-acylhomoserine lactone acylase from Pseudoalteromonas flavipulchra. Microbiology 2017, 163, 1389-1398. [CrossRef]

103. Glinel, K.; Thebault, P.; Humblot, V.; Pradier, C.M.; Jouenne, T. Antibacterial surfaces developed from bio-inspired approaches. Acta Biomater. 2012, 8, 1670-1684. [CrossRef] [PubMed]

(C) 2019 by the authors. Licensee MDPI, Basel, Switzerland. This article is an open access article distributed under the terms and conditions of the Creative Commons Attribution (CC BY) license (http://creativecommons.org/licenses/by/4.0/). 